\title{
Evolution and Modern Approaches of the Power Transformer Cost Optimization Methods
}

\author{
Tamás Orosz ${ }^{1 *}$ \\ 1 Department of Theory of Electrical Engineering, Faculty of Electrical Engineering, University of West Bohemia, \\ Universitni 26, 30614 Pilsen, Czech Republic \\ *Corresponding author, e-mail: tamas@kte.zcu.cz
}

Received: 14 August 2018, Accepted: 04 October 2018, Published online: 21 January 2019

\begin{abstract}
Transformer design is a challenging engineering task, where the different physical fields have to be harmonized together to fulfill the implied specifications. Due to the difficulty of this task, it can be separated into several subproblems. The first subproblem, in the pre-concept phase, during the transformer design is the calculation of the cost optimal key-design parameters, where not only the technical but also the economical parameters have to be considered, as well. This subproblem belongs to the most general branch of the non-linear mathematical optimization problems. This paper presents the main directions of the evolution and trends in the power transformer design. Main directions of the considered research and the future trends in the field of preliminary design transformer optimization methods are summarized.
\end{abstract}

Keywords

power transformer, design optimization, mathematical optimization

\section{Introduction}

The design process of a power transformer is a complex optimization task, where not only the technological requirements but also the influence of the economic feasibility have to be considered. Moreover, the design methodology may vary significantly according to the transformer type (e.g.: core or shell form, instrument transformer) and the applied manufacturing technology [1].

To create a competitive design, many non-linear constraints have to be considered simultaneously to fulfill the imposed specifications. The searched design parameters can interact with each other and belong to different physical domains - such as electrical, thermal, mechanical, etc. Therefore, the design of power transformers generally leads to a coupled, multidisciplinary optimization problem, where the problem is not only to find a feasible solution but also the cost-optimal solution [2].

Due to the complexity of the problem, classically, the design process of a power transformer is divided into the following three subproblems [3-5] (Fig. 1):

- Pre-concept stage:

The cost optimization of a transformer design is made in the preliminary (pre-concept, tender) design stage. The result is a design study, a simplified

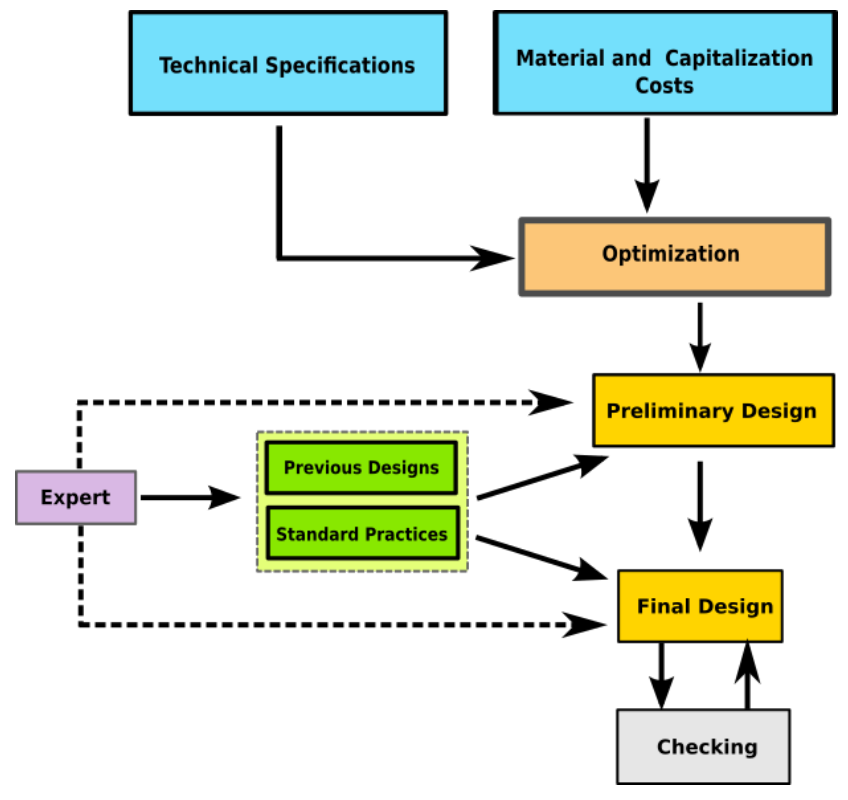

Fig. 1 The classical transformer design partitions $[2,6]$.

design, which is usually sufficient for the proposition and a state of requisition. The design variables or parameters of this concept study is called the key-design parameters. 
- Final design stage:

The final design is essentially the refinement of the preliminary design to the most minute and complete details. Its output is the final design engineering record and the drafting and manufacturing instructions.

- Checking stage:

Checking of the final design, usually by another designer.

This paper focuses on the optimization methods and approaches used in the pre-concept stage.

The mathematical representation of this transformer design optimization subproblem belongs to the most general branch of the non-linear mathematical optimization methods [7-9]. The first analytical methods were introduced at the beginning of the twentieth century [10] - only some years later than the first power transformers were produced [11] - showing the importance of the topic. One of the first application of the digital computers in the transformer industry is an iterative solution for this design optimization subproblem $[2,3,8]$.

During the last century not only the applied methods have been evolved, but also the transformer industry, the manufacturing methods, the construction of the transformers and the applied materials have been evolved a lot. The first analytical methods just considered oversimplified models consisting of only the active materials, such as the core and the windings. These models neglected the impact of neglecting the cooling, the insulation system or other non-linear component at this pre-concept design phase [7, 12-14].

This paper provides an overview from the evolution of these cost optimization methods, based on extensive number of publications.

\section{Trends in Transformer Technology}

A wide range of transformer types exists from the small electronic devices till the largest components of the power transmission network. Although these devices are based on the same physical principle, viz. the electromagnetic induction. They can be categorized in several different ways: by their rated power (Fig. 2), the type of the application, manufacturing technology etc.

This paper focuses on the evolution of the preliminary design methods, which relates with large power transformers (LPT). LPT is a large, custom-built equipment in the bulk transmission grid. LPTs are very expensive, unique machines, tailored to the customers' requirements

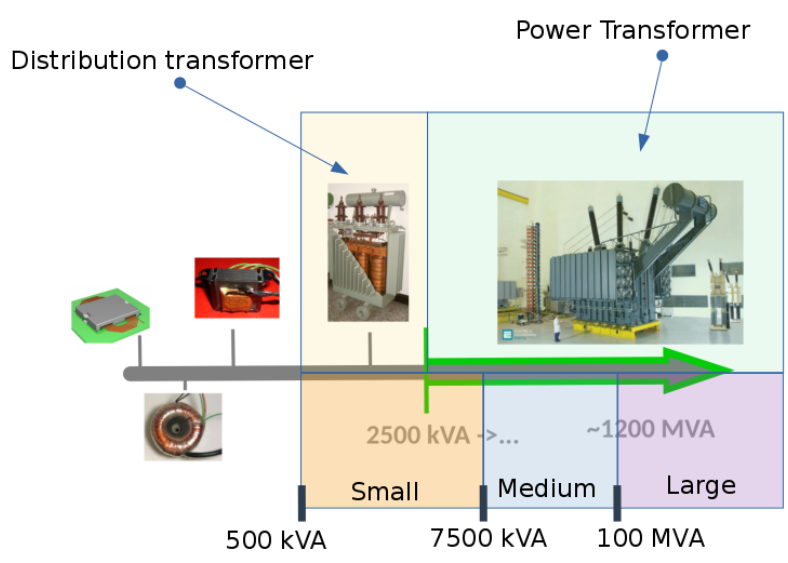

Fig. 2 Categorization of different transformer types by their nominal power and possible categorization of power transformers.

according to individual factors such as voltage, power, climate, system topology, sound level and others. Therefore these machines are usually not interchangeable, thus the reliability is a key factor [15].

The power rating level of this transformer category has been increased a lot during the last century due to the advancements of applied materials and manufacturing technology [7, 9, 16-20]. The first power transformer was shipped on September 16, 1884 by Ganz \& Company. This first unit was a one-phase, shell-form transformer with the following specifications: $1400 \mathrm{~W}$ rated power, $42 \mathrm{~Hz}$ network frequency, 120/72 Volts, 11.6/19.4 Amperes, and 1.67:1 turn ratio [11, 21-24]. The first three-phase unit developed soon at the Allgemeine Elektricitäts- Gesellschaft ('General Electricity Company') in 1899 [25]. The rated power of the above mentioned first core-form power transformer units was lesser than $10 \mathrm{kVA}$ (Fig. 3) [11, 26]. Interestingly, this power rate would not be considered as a power transformer according to the nowadays classification.

The need for increasing grid power and larger distances induced the usage of larger power transformer units and

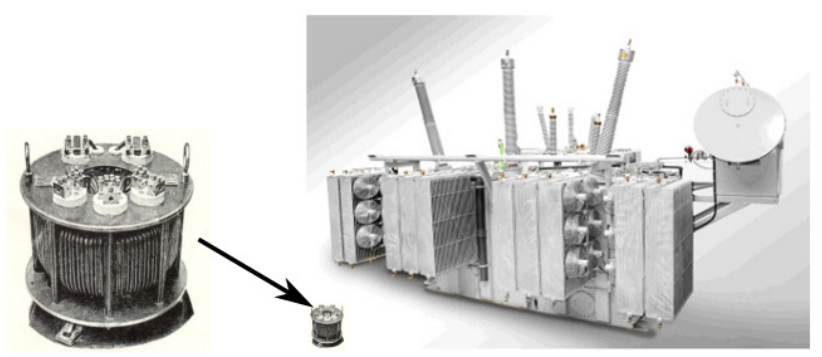

Fig. 3 The left side of the picture shows one of the first core type power transformers, manufactured at the GANZ factory in 1886, rated power was $7.5 \mathrm{~kW}$ [27]. On the right-side the size of this transformer is compared with a modern large power transformer. 
the usage of larger voltage levels due to economic reasons [18]. Nowadays, the nominal power of the largest transformers reaches the $1500 \mathrm{MVA}$ and the applied high voltage level is more than $1000 \mathrm{kV}[20,28,29]$. The transformer business and the load of a transformer design has doubled in every 11 years till 1945 when standardized, repetitive transformer designs were introduced from 500 to $10000 \mathrm{kVA}$ to reduce the engineering work and the shipment times [2].

Nowadays, the term LPT refers to those power transformers which have more than 2,500 kVA rated power and do not include a winding intended for connection to the low-voltage distribution network (Fig. 3) [16, 17, 30]. The common in the large power transformers from the different decades of the last century is that they are too large or too complex for bulk production. Thus, these machines are designed customly for the specific requirements of the application, for example [15] states that approximately 1.3 LPTs are produced for each transformer design [16].

Due to the growth of the rated power the load and the no-load losses are increased as well. In the case of large power transformers the sum of these losses can be hundreds of kilowatts. Accordingly, the diversion of heat is a challenging engineering task. Different winding and cooling systems with direct and natural oil flow has been introduced to solve this problem [17, 18, 31, 32].

One of the main challenges in insulation system design is that the insulation system has to withstand the surge phenomena and the overvoltages likely occur to its operation $[7,9,18,33]$. To achieve an adequate insulation system, the electric field distribution during a lightning or a switching impulse test designed by extensive usage of the numerical methods [17, 34-37]. A further exceptionaly challenging task is to model the frequency dependent behavior of the insulation system, because the value of the dielectric model parameters are strongly dependent from the frequency [37-41]. On top of this, the calculation of the breakdown phenomenon in the transformer oil is so complex that there is no a widely accepted model exist [28, 42-44].

Due to the increment in the nominal voltage levels and the aspect of the cost effectiveness there is a deep interest to find insulation materials with better dielectric properties. The basis of the insulation oils hasn't been changed significantly from the first transformer oil, which was patented by Thompson in 1892 [9]. However, there was a huge development in the cleaning and the manufacturing processes of the oils and in the applied additives [9, 18, 45-47]. Basically, two types of mineral oil based transformer oil are used: paraffinic-based and the naphthenic-based oils [48]. During the aging processes insoluble sludge has been produced in the case of paraffinic-based oils. This sludge increases the pour point, the viscosity of the oil and causes overheating and reduced service life [48]. Naphthenicbased oils has been developed to overcome these limitations, which with aromatic compounds can remain fluid at $-40{ }^{\circ} \mathrm{C}$ But nowadays, the isoparaffinic based oils can have better performance [49]. Other disadvantage of the mineral based oils is their inflammability and they are not biodegradable, viz. not environment friendly materials.

Not only mineral oil based insulation liquids are used in power transformers. Polychlorinated biphenyl (PCB) based insulation materials has been widely applied in the electrical apparatus where the fire safety was the most intrinsic design criteria $[9,45]$. Till the end of the 60 's when PCB's environmental toxicity was proved and the PCB's was classified as persistent organic compounds [50].

Since then the silicon oil and the synthetic ester based insulation liquids, which flashing point are above than $300{ }^{\circ} \mathrm{C}$ are successfully applied in fire hazardous environments. There are many other attempts with the application of the SF6 gas in power transformers [51]. In the last twenty years, the most promising trend is the replacement of the mineral oils with biodegradable, natural ester based liquids [48, 52-55]. Both the thermal and the dielectric properties of these materials are very promising. Nowadays, these materials are competitive and good alternatives for the mineral oil based insulation liquids. Since their viscosity and aging parameters can be significantly different from the conventional transformer oils. The application of these new insulation liquids can have a significant effect on the key-design parameters of the cost optimal power transformer design [19].

In the last century, there was a huge improvement in the solid insulation materials as well. The cellulose based insulation materials spread around the industry. In spite of that the cellulose is not the most proper material for this function. However, there are a large amount of cheap raw material to manufacture this insulation, e.g. the soft wood [24]. Before 1920, besides the cellulose, which was meant resin impregnated paper at that time, many fiber structured materials like cotton, jute, silk and asbestos based materials were tried as electrical insulation $[45,56,57]$.

In the 1920-1930's there was a huge improvement on the manufacturing technology of the papers and a lot of new additives were found which improve significantly the structure and the dielectric properties of the paper. 
One of the key achievements of these research works was the kraft paper based insulation system and the pressboard which was patented by Weidmann. These novelties made it possible to drastically increase the voltage and the power levels of the electric grid in the 40's [24].

A small progress can be noticed in the development of the synthetic insulation materials and the epoxy based insulations, structural parts. The improvements in the enamel technology leads to the application of the continuously transposed cables (CTC), which has better filling factor and can reduce the stray losses due to their better electrical parameters. The papers have been improved a lot in the 70's, the Dennison Paper Company introduced the crepp paper, which has $20 \%$ greater elasticity than the normal papers, besides the thermal upgraded papers were introduced in the second half of the century [24,58]. A lot of attempts were made to chemically modify the cellulose molecules. The most important result of these attempts is the Nomex, which can be used in the case of higher load temperatures at $220{ }^{\circ} \mathrm{C}$ instead of $105{ }^{\circ} \mathrm{C}$ as the normal papers $[24,28]$.

The electrical steels have the biggest improvement in the transformer industry at the last century (Table 1). At the beginning of XX.century, soft magnetic steel was used as an iron core. At the Ganz-factory, these steels were replaced by $2 \%$ of aluminum alloyed steels to reduce the hysteresis and the eddy current losses in iron cores [27]. Because of the other outcome of the high core losses was a high temperate gradient near the transformer core, which increased the aging processes. The average lifetime of the transformers was 8-10 years at the beginnings of the industry when soft magnetic steels were applied in the transformer cores [27]. The aluminum alloyed materials solved this issue. After a few years, the silicon alloyed steels were quickly spreaded around the industry as a better alternative.

Due to the inventions in the metallurgical technologies, grain oriented silicon steels have been processed already in the 1930s (Table 1). Where the direction of the grains is as the same as the rolling direction. This can be significantly decrease the hysteresis losses in a specific direction. In the 1970's Japan was taken the lead in the steel manufacturing also in the case of the electrical steels. Because, with the application of new metallurgical technologies the magnetic losses of the electrical steels have been reduced significantly. These new materials are called Hi-B (Table 1) and produced in several countries around the world by the same license. In the 80 's a most of the
Table 1 Development of the magnetic steels $[17,27]$

\begin{tabular}{lc}
\hline First application date & Material \\
\hline 1885 & soft magnetic steels \\
$1890-1900$ & soft magnetic steel with aluminum alloy \\
1900 & Si alloyed steels \\
1935 & grain oriented Si alloyed steels \\
1970 & Hi-B \\
1980 & thin Hi-B \\
1983 & domain refined grain oriented electrical steels \\
1990 & Very thin electrical steels \\
\hline
\end{tabular}

Table 2 Loss of some electrical steel sheets at 1.7 T. [17]

\begin{tabular}{lcc}
\hline Type & $\begin{array}{c}\text { Losses }-50 \mathrm{~Hz} \\
1.7 \mathrm{~T}[\mathrm{~W} / \mathrm{kg}]\end{array}$ \\
\hline Conventional & M111-35N & 1.41 \\
& M097-30N & 1.30 \\
& M089-27N & 1.23 \\
\hline Hi-B & M117-30P & 1.12 \\
& M105-30P & 1.00 \\
& M100-23P & 0.92 \\
\hline Laser refined Hi-B & 27-ZDKH & 0.92 \\
& 23ZDKH & 0.84 \\
\hline
\end{tabular}

steel manufacturers have started to produce thinner steel sheets. The average steel sheet thickness was $0.35 \mathrm{~mm}$ in the 1960 's. At the 80 's they reduced to a thickness of $0.05 \mathrm{~mm}$. The advancements in the insulations has an important contribution to the reduction of the lamination thickness $[59,60]$. However, working with these thin steel sheets is expensive as it requires special tools.

The core loss reduction is achieved by alternative, more economical methods (Table 2). Most likely, laser scribing of the grain oriented steel sheets is used to break up the long grains in the 'Hi-B' steels to allow easier rotation of those grains in a magnetic field making the steel much easier to magnetise [17]. Other advantage of these methods is the reduced noise level (reduction by 2-3 dBA).

The achievements of the last decades have unexpected twists in the direction of the transformer development. For example, there are comprehensive researches are in progress on the application of superconducting materials in power transformers [61-69].

\section{Analytical Cost Optimization Methods}

Transformer design engineers have long strived for a theoretically confirmed and practical method to reach the cost optimal key-design parameters in the preliminary design 
stage $[14,70]$. The first analyitical methods were published a long time ago at the dawn of the transformer industry [10]. The construction of transformers has been improved a lot, parallel with these preliminary optimization methods [71]. Gisbert Kapp [10] demonstrated a relationship between the volume of the iron core and the power of the power transformer in as early as 1900. In 1906 Bohle has already created a simple model, where he alredy considered the impact of the economic environment on the optimal dimensions of an electrical machine. He assumed that the material cost of the transformers active part $(P)$ can be expressed as a function of the transformers efficiency $(\eta)$ :

$P=f(\eta)$.

Then he divided the total cost of the transformer into two parts: the cost of the active and the inactive (or fix) parts:

$P_{t}=p C+p f c(\eta)$

where $C$ and $c$ are empirical constants, with values are selected between $0.5 \mathrm{P}$ and $1.5 \mathrm{P}$, considering applied technology and economic environment [72], and $\mathrm{p}$ is an economical constant which is calculted from amortization and investment. He extended the above cost function with the losses as a function of efficiency $(F(\eta))$, thus he searched for the minimum of the following function:

$\min \{p C+p f c(\eta)+F(\eta)\}$.

In [72] he introduced that:

$\tan (\alpha)=F /(\eta)$,

$\tan (\beta)=f /(\eta)$.

The minimum of the equation system, viz. the optimal ratio of the losses and the cost of the acitve part was expressed by the following equation:

$\frac{\tan (\alpha)}{\tan (\beta)}=\frac{-1}{p c}$.

The main weakness of this approach is not distingushing between the load and the no-load losses. The method was tested on a simple pulse transformer, where the short-circuit losses can be negligible [72]. Therefore, only the core losses and the cost of the active part are considered in this case [72] and the optimal value for the core-copper ratio can be calculeted by a simple graphical method, as the intersection of the two function. Due to the neglection of the load losses and many important design parameters, this model is not applicable to reach the required accuracy.
As early as 1909 the Ganz \& Co. factory produced transformers with different core and copper ratios for the fossil fuel and hydroelectric power plants. In spite of the fact that the concept of capitalized losses is not known at this time to consider the lifetime losses they have intuitively discovered that the optimal transformer design is different in the case of the different power plant types $[12,27]$. The main difference between these two plant types that there are no fuel cost in the case of a hydroelectric plant and these plants generates consistent power during the whole year contrast to the fossil fuel power plants, which generate their maximal power at winter in their peak season. To consider the differences between these characteristics of the two power plant types they have produced transformers with larger iron cores, viz. smaller no-load losses and higher efficiency for the hydroelectric plants. These designs were more expensive than the others designed for steam power plants.

The economic collapse after the First World War had changed the established manufacturing and design practices. Instead of minimizing the lifetime cost of an electrical machine, the designers had striven to minimize the mass of the transformers active part. Hence, these machines has high load and core losses, thus the cooling of the transformers were the main design problem in this era.

Waldo [73] has published an optimization model in 1929 already considering both the load and no-load losses during the determination of the optimal core and copper ratio. His approach had already used the filling factors to model the different winding and core types, while many substantial design parameters, like short-circuit-impedance or the efficiency had not been considered.

A considerable literature has grown up around this topic, a lot of analytical methods have been developed till the beginning of the computer era [74-77]. These new, nowadays well-known, findings has made quantitative statements on the core-copper ratio and the growing trends of the electrical machines [77]:

- The volume of the transformer $(\mathrm{V})$ depends on the nominal power $(\mathrm{P})$ - if the voltage level is constant on the following way: $\mathrm{V} \sim \mathrm{P} 4$,

- the cost optimal parameters of the transformer can be found, if the volume of the transformer is given if the $\{$ cost of the load losses $\}=\{$ cost of the active part + cost of the no-load losses $\}$,

- or if the power of the transformer is given, then the $\{$ cost of the load losses $\}=\{$ cost of the active part + cost of the no-load losses\}, 
These methods generally model the transformer only by the active part neglecting the cooling system and the structural components, which together represent about the half of the total manufacturing cost $[17,78]$. These active part models use only a two-winding model neglecting the impact of the regulating winding on the key-design parameters [13]. Other common assumption of these analytical methods is that they neglect the insulation materials and us the minimal insulation distances as con- straints. However, the properties of the dielectric materials have a complex non-linear behavior and the idea of the minimization of the insulation cannot guarantee that we find the most economical solution [13, 14].

The application of these oversimplified analytical models easily leads to erroneous design rules and practices which can easily misleads the non-experienced designer in the case of a special application or produces non- economical designs after the changing of the conditions. The interest for fast and accurate analytical methods is not decreased after the spreading of the computer based numerical solutions [79].

The first computer aided design method for electrical machines was one published by Abetti in 1953 [3]. Then Sharpley and Oldfield [80] in 1958 and Williams et al. in 1958 [81] published the first research papers from the computer aided transformer design. These methods have used a simple iteration to find the optimal key-design parameters in the pre-conceptional design phase. The computers got around the transformer industry in the 50's. They allowed to automatize routine calculations and made it possible to apply new, advanced numerical methods, which is required by the new improvements on the voltage level and the higher reliability requirements. Due to the increased accuracy, the appropriate solution of the different physical fields leads to solve elliptic integrals, second order Bessel-functions etc. These partial differential equations can be solved by numerical methods in reasonable time and accuracy [1, 82-101].

The solution of the preliminary design tasks were one of the first application field of the computers in the transformer industry. Because the rapid solution of these optimization tasks ensured a significant advantage in the competing market [82]. The first systematic approach for the computer aided design of electrical machines was given by Abetti et al. [2]. This design approach has not been obsolated till today, this method is described and illustrated in Fig. 1. There are many similar methods in the industry. Dicső and Petras published a similar method on the other side of the iron curtain [82]. However, the original approach was not considered the material and the capitalization costs. With the consideration of the lifetime costs, the solution of this transformer optimization problem is a much more complex problem as illustrated in Fig. 3. Furthermore, not only the key-design parameters of a power transformer are highly depends on the material and the capitalization costs, but also the specification of the transformer as well [7, 30, 91, 97].

In the 50's and 60's the preferred transformer design methods has been determined the product price $(P)$ and nominal power $(S)$ - therefore the optimal core and copper ratio - as a function of the core geometry. These geometrical shape functions $\left(f_{1}, f_{2}, f_{3}\right)$ was calculated from the core diameter $\left(D_{o}\right)$, the length of the yoke and the legs $\left(l_{j}, l_{o}\right)$. One of the latest algorithm from this design philosophy was published by Bulgakov [102]:

$$
\begin{aligned}
& P=f_{1}\left(D_{o}, x, y\right), \\
& S=f_{2}\left(D_{o}, x, y\right), \\
& x=f_{3}(y), l_{o}=x D_{o}, l_{j}=x D_{o} .
\end{aligned}
$$

The main weakness of this design method is that the $f_{1}$ and $f_{2}$ formulas contains the ratio of the core diameter and the working window as a constraint. However, this ratio depends on many other key-design parameters, like the current density, rated voltage and the rated power of the windings [98]. The optimal yoke-leg ratio from this calculation algorithm is between $3.4<l_{o} / l_{j}<4$, which corresponds with the manufacturing statistics. However, the knowledge of these parameters does not supports the design process. Moreover, it indirectly proves that the manufacturing costs mainly depend on the magnetic flux, current density and the losses instead of these newly introduced $\left(D_{o}, x, y\right)$ quantities [103].

The advancement of the manufacturing processes, the applied materials and the increased electrical and mechanical stresses eventuated the reduction of the manufacturing costs in this era $[12,103]$. Due to the increased stresses and reduced sizes the transformers were designed with relatively high core diameter and thin windings at that era. This trend led to wrong constructing principles, which increased the manufacturing costs and the nominal losses if the transformers were too big for this technology.

In the beginning of the 60's, Csikós [103] recommended a new procedure, which in contrast to the actual design principles, proposed to decrease the operating cost instead 
of the manufacturing cost. The recommended formula was the following:

$$
K=p k / 100+t W,
$$

where $p$ means the percentage value of the sum of the acquisition, maintenance and installation costs, $W$ the annual loss in $\mathrm{kWh}$ and $\mathrm{t}$ is the unit price of the electricity. However, this formula was not considered the lifetime of the machine, and the inflation and rate of interest during the life cycle of the machine. This formula was not differentiate between the load and the no-load losses, therefore it was not considered the annual load (Eq. (10)) of the transformer. Moreover, the applied analytical model used that design directive as an axiom [45], which states that the insulation system of an electrical machine is properly designed, if the applied safety factor is close to the minimum of the resultant curve $\left(E_{\text {load }}=E_{\text {allowed }}\right)$ (Fig. 4). Following this axiom, the application of larger main gap increases the cost of the active part of an electrical machine. Due to the non-linearity of the electrical machine design problem this design principle does not corresponds with the practice, where the cost optimal transformers, autotransforemrs have larger main gap than the required minimum $[5,8,13,14,104]$. Csikos has already confuted another old design rule [103], which states that if the transformer designed for maximal efficiency it has as same load as no-load losses. Because the selection of the geometrical and the electrical parameters are not the same in the case of the two different objective functions: the maximal efficiency or the minimal losses [105]. He rejected to use the manufacturing cost as the objective function, instead of this he was proposed to use the sum of the manufacturing and the operating costs as the objective of the optimization. This phenomenon is similar to the modern lifetime cost optimization approaches [1, 91, 103-107] (Fig. 5).

Numerous computer aided design methods were introduced at the end of the 70's to determine the optimal key-design parameters [1,91]. Most of these algorithms solved a significantly simplified transformer models with a heuristic search or a simple iteration to find a convenient, economical solution [108-119]. These heuristical solvers were generally used abstract or empirical constraints, equalities and inequalities to simplify optimization problem and shortening the solution time. Nevertheless the application of these simplifications and abstractions makes it impossible to find the solution of the original optimization problem. As the method was presented in [116], which used the same analytical approach

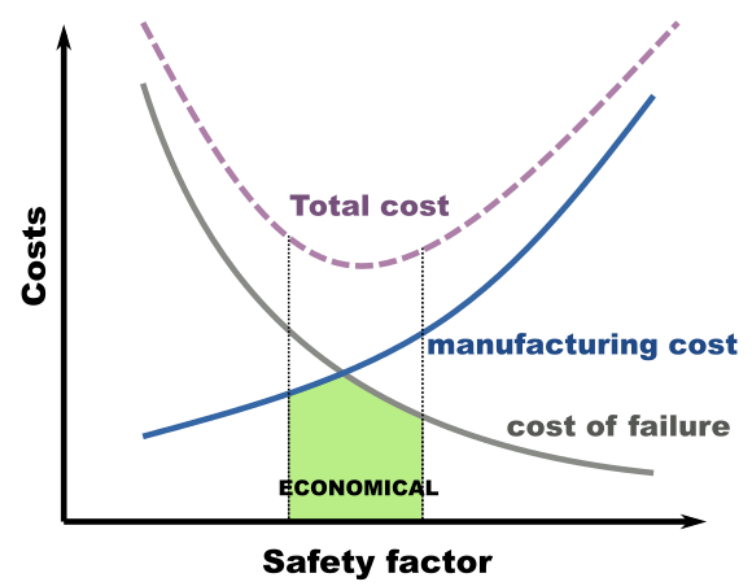

Fig. 4 A properly designed insulation system ensures continuous operation during the planned lifetime of the electrical machine. Otherwise, the cost of the operation failure can significantly increases the lifetime costs. The classi- cal design rules assumes that the manufacturing cost of an electrical machine directly proportional with the size of the insulation, electrical machine. Hence, the economically optimal insulation system can be found near the minimum of the resultant function of the manufacturing cost and cost of failure functions, when $\left(E_{\text {load }}=E_{\text {allowed }}\right)[45]$.

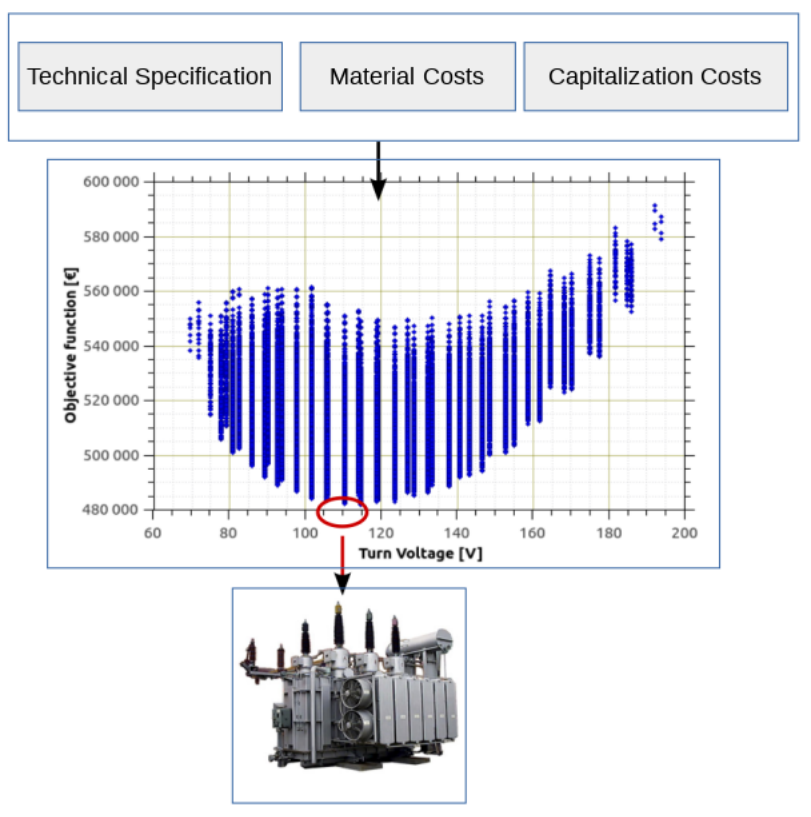

Fig. 5 Complexity of the preliminary design stage. The figure illustrates the number of the possible designs for the preliminary design optimization problem, if the lifetime costs are considered.

as (Eq. (10)), viz. this method was determined the minimal mass transformer design based on the core geometry, they neglected important variables like the flux density, the current density in the windings or the short-circuit impedance. These multifarious methods are similar in that they neglected the details of the transformer 
windings and just calculated by the sum of the excitation and the filling factor of the windings [70].

Újházy has published an algorithm, which calculates the detailed winding parameters from the key-design parameters, e.g. the results of these preliminary optimization solvers $[12,70]$. This method was based on the assumption that the transformer optimization process can be separated into two independent optimization tasks: the optimization of the core and the windings. The outcome of this assumption is that the aforementioned method does not consider the retraction of the optimal key-design parameters of the windings on the core parameters.

Andersen has developed a Monte Carlo method based transformer optimization code (MONICA [118]) to determine the optimal key-design parameters. This method was published already in 1967 and extended for electrical machine optimization, because of the simplicity and robustness of the code. Sarovalac [120] introduced a method, which - similarly to MONICA - generated a set of feasible designs and searched the minimal cost design as a continuous mathematical optimization problem.

Judd and Kessler [121] published a mathematical programming based algorithm, which determines the winding geometry with the maximal load capability for an existing iron core geometry. Poloujadoff and Findlay [122] made a simple iterative solver to analyze the sensitivity of the input parameters on the key-design variables.

At the end of the 20th century, most of the published methods have used the lifetime cost of the transformer to determine the cost-optimal key-design parameters $[1,14,91]$. A lot of papers and a standardized methodology [123] has been published at that time which deal with the more complex and accurate evaluation of the capitalization factors [91, 97, 103, 124-128]. The latest methods take into consideration not only the economic but the environmental aspects as well $[91,126,128]$. Numerous FEM based optimization methods have been developed during these years to make a more accurate algorithm which can take more aspects into consideration at the beginning of the design process [9, 7, 17, 129-132]. Majority of these methods combine the FEM method with a heuristical or mathematical programming based optimization technique [30, 91, 133-137]. Most of these methods have searched the global cost optimum for a power transformer [33, 138-141]. The others have calculated the optimal winding distribution or another optimization subproblem [142], like [12].

Several new transformer optimization methods has been published in the recent decades, which methods applied the recent advancements of the numerical computing methods: ssuch as neural networks [143, 144], nature inspired evolutionary, genetic algorithms [143-157] and metaheuristic type optimization methods combined with FEM [148]. Because of the difficulty of the cost optimization problem, beside the numerical methods, the analytical transformer models was developed further [4, 149-151]. However, most of these analytical methods optimizes for the manufacturing not the lifetime cost of the transformer [148], or solves some smaller sub-optimization task [152-154].

The transformer optimization problem belongs to the most general branch of the non-linear, mixed integer mathematical optimization problems. Majority of the optimization methods combines FEM and analytical calculation methods with a metaheuristic, branch and bound method technique [154-157]. One of the first application of the geometric programming was the cost optimization of power transformers [8, 158]. In 2005, Jabr [159] made a transformer optimization algorithm with a modern, interior-point method solver. The main advantages of the geometric programming formalism are the following: the formalism guarantees that the obtained solution is the global solution and relatively large inequality systems can be solved in a small computer in very short time [158-161]. However, as it was proved by [5] the geometric programming formalism cannot be used for core- form power transformers, because the short-circuit impedance constraint cannot be formulated in the required posynomial form [78]. Combining the geometric programming with the method of branch and bound, a new metaheuristic solver was published [5]. This new solver is relatively fast and robust compared to other methods [4] and it can be extended to consider the effect of the outer cooling system [78] and the impact of the tap-changing method on the cost-optimal design [13].

\section{Conclusion}

In the present paper, an overview of the literature concerning the preliminary design optimization methods for power transformers has been undertaken. Relevant publications from international journals have been selected, covering a broad range of engineering and numerical methods. As it can be seen from the numerous publications this is an actively researched field. The methodology and the construction of the transformers are evolving together. The novel transformer optimization methods consider more complex transformer models and the recent results of the optimization theory. Not only the transformer models, 
but also the optimization aspects has been changed a lot. These models are common in that they are determined the active part parameters by their active components and

\section{References}

[1] Amoiralis, E. I., Tsili, M. A., Kladas, A. G. "Transformer Design and Optimization: A Literature Survey", IEEE Transactions on Power Delivery, , 24(4), pp. 1999-2024, 2009. https://doi.org/10.1109/TPWRD.2009.2028763

[2] Abetti, P. A., Cuthbertson, W. J., Williams, S. B. "Philosophy of Applying Digital Computers to the Design of Electric Apparatus", Transactions of the American Institute of Electrical Engineers, Part I: Communication and Electronics, 77(3), pp. 367-379, 1958. https://doi.org/10.1109/TCE.1958.6372814

[3] Williams, S. B., Abetti, P. A., Magnusson, E. F. "Application of Digital Computers to Transformer Design", Transactions of the American In- stitute of Electrical Engineers. Part III: Power Apparatus and Systems, 75(3), pp. 728-735, 1956. https://doi.org/10.1109/AIEEPAS.1956.4499359

[4] Orosz, T., Borbély, B., Tamus, Z. Á. "Performance Comparison of Multi Design Method and Meta-Heuristic Methods for Optimal Preliminary Design of Core-Form Power Transformers", Periodica Polytechnica Electrical Engineering and Computer Science, 61(1), pp. 69-76, 2017.

https://doi.org/10.3311/PPee.10207

[5] Orosz, T., Sleisz, Á, Tamus, Z. Á. "Metaheuristic Optimization Preliminary Design Process of Core-Form Autotransformers", IEEE Transactions on Magnetics, 52(4), pp. 1-10, 2016. https://oi.org/10.1109/TMAG.2015.2496905

[6] Orosz, T., Kleizer, G., Iváncsy, T., Tamus, Z. Á. "Comparison of Methods for Calculation of Core-Form Power Transformer's Core Temperature Rise", Periodica Polytechnica Electrical Engineering and Computer Science, 60(2), pp. 88-95, 2016.

https://doi.org/10.3311/PPee.8893

[7] Del Vecchio, R. M., Poulin, B., Feghali, P. T., Shah, D. M., Ahuja, R. "Transformer Design Principles: With Applications to Core-Form Power Transformers", 2nd ed., CRC Press, Hoboken, USA, 2010.

[8] Del Vecchio, R. M., Poulin, B., Feghali, P. T., Shah, D. M., Ahuja, R. "Transformer Design Principles: With Applications to Core-Form Power Transformers", 1st ed., CRC Press, 2002.

[9] Kulkarni, S. V., Khaparde S. A. "Transformer engineering: design, technology, and diagnostics", 2nd ed., CRC Press, Boca Raton, FL, USA, 2016.

[10] Kapp, G. "Transformatoren für Wechselstrom und Drehstrom" (Transformers for Single and Multiphase Currents: A Treatise on Their Theory, Construction, and Use), Charleston SC, United States: Nabu Press, 2012

[11] Jeszenszky, S. "History of Transformers", IEEE Power Engineering Review, 16(12), p. 9, 1996. https://doi.org/10.1109/MPER.1996.546444

[12] Újházy, G. "Erőátviteli transzformátorok gépi számításának kérdései" (Application of Computers for Power Transformer Design), PhD Thesis, Budapest University of Technology and Economics, 1969. (in Hungarian) neglects the impact of the insulation system. The consideration of the impact of the insulation system on this general non-linear optimization problem is the task for the future.

[13] Orosz, T., Tamus, Z. Á. "Impact of short-circuit impedance and tap changing method selection on the key-design parameters of core-form power transformers", Electrical Engineering, 100(3), pp. 1631-1637, 2018. https://doi.org/10.1007/s00202-017-0642-z

[14] Orosz, T. "Összetett szigetelési rendszerek optimalizálása: Nagytranszformátorok tervezése esetén" (Optimization of complex insulation systems in the case of power transformers), $\mathrm{PhD}$ Thesis, Budapest University of Technology and Economics, 2017. (in Hungarian)

[15] T. Y. C. of ICF International "Large power transformers and the u.s. electrical grid", Infrastructure Security and Energy Restoration Office of Electricity Delivery and Energy Reliability U.S. Department of Energy, 2012.

[16] Harlow, J. H. "Electric power transformer engineering", 3rd ed., CRC Press, Boca Raton, USA, 2012.

[17] Ryan, H. M. "High Voltage Engineering and Testing", 3rd ed., IET, London, UK, 2013.

[18] Karsai, K., Kerényi, D., Kiss, L. "Large power transformers", Elsevier Science Pub. Co. Inc., New York, NY, USA, 1987.

[19] Prevost, T. A. "Dielectric properties of natural esters and their influence on transformer insulation system design and performance", In: 2009 IEEE Power \& Energy Society General Meeting, Calgary, Canada, 2009, pp. 1-7. httpsw://doi.org/10.1109/PES.2009.5275167

[20] Nayak, R., Sasmal, R., Sehgal, Y., Rashwan, M., Flisberg, G. "Technical feasibility and research \& development needs for 1000 kv and above hvdc system", presented at 2010 Cigré Session, Paris, Aug, 10, 2010.

[21] Zipernowsky, K., Déry, M., Bláthy, O. T. "op buda-pesth", USA, No. 352,105, 1886.

[22] Halacsy, A., Von Fuchs, G. H. "Transformer Invented 75 Years Ago", Transactions of the American Institute of Electrical Engineers. Part III: Power Apparatus and Systems, 80(6), pp. 121125, 1961.

https://doi.org/10.1109/AIEEPAS.1961.4500994

[23] Allan, D. "IEE power division: Chairman's address. Power transformers-the second century", Power Engineering Journal, 5(1), pp. 5-14, 1991. https://oi.org/10.1049/pe:19910004

[24] Prevost, T. A., Oommen, T. V. "Cellulose Insulation in Oil-Filled Power Transformers: Part I - History and Development", IEEE Electrical Insulation Magazine, 22(1), pp. 28-35, 2006. https://doi.org/10.1109/MEI.2006.1618969

[25] Neidhöfer, G. "Az első Ganz-tranzformátorok adatai" (Data of the first ganz power transformers), VDE Verlag, Berlin, Offenbach, 2004. (in Hungarian)

[26] Ganz Company, "Az első Ganz-tranzformatorok adatai" (Data of the first ganz power transformers), 1960. (in Hungarian) 
[27] Ziomek, W. "Transformer electrical insulation [editorial]", IEEE Transactions on Dielectrics and Electrical Insulation, 19(6), pp. 1841-1842, 2012. https://doi.org/10.1109/TDEI.2012.6396938

[28] Antal, F. "Az 50 éves transzformátor" (The 50 years old trans- former), Ganz Közlemények, 16, 10-23 1935. (in Hungarian)

[29] Huang, D., Shu, Y., Ruan, J., Hu, Y. "Ultra High Voltage Transmission in China: Developments, Current Status and Future Prospects", Proceedings of the IEEE, 97(3), pp. 555-583, 2009. https://doi.org/10.1109/JPROC.2009.2013613

[30] Georgilakis, P. S. "Spotlight on Modern Transformer Design", Springer-Verlag, London, UK, 2009. https://doi.org/10.1007/978-1-84882-667-0

[31] Smolka, J. "CFD-based 3-d optimization of the mutual coil configuration for the effective cooling of an electrical transformer", Applied Thermal Engineering, 50(1), pp. 124-133, 2013. https://doi.org/10.1016/j.applthermaleng.2012.06.012

[32] Dombek, G., Nadolny, Z. "Liquid kind, temperature, moisture, and ageing as an operating parameters conditioning reliability of transformer cooling system", Eksploatacja i Niezawodnosc Maintenance and Reliability, 18(3), pp. 413-417, 2016. https://doi.org/10.17531/ein.2016.3.13

[33] Amoiralis, E. I., Georgilakis, P. S., Tsili, M. A., Kladas, A. G., Souflaris, T. "Complete software package for transformer design optimization and economic evaluation analysis", In: Materials Science Forum, Vol. 670, pp. 535-546, 2011. https://doi.org/10.4028/www.scientific.net/MSF.670.535

[34] Elmer, G. "High frequency quasi distributed parameters for onelayer straight coils", Pollack Periodica, 1(3), pp. 103-114, 2006. https://doi.org/10.1556/Pollack.1.2006.3.8

[35] Gomez, P., De León, F. "Accurate and Efficient Computation of the Inductance Matrix of Transformer Windings for the Simulation of Very Fast Transients", IEEE Transactions on power Delivery, 26(3), pp. 1423-1431, 2011. https://doi.org/10.1109/TPWRD.2011.2104370

[36] Tapiawala, G., Mishra, R. K. "Comprehensive modeling of dry type foil winding transformer to analyse inter turn insulation under lightning impulse voltage", In: 2016 National Power Systems Conference (NPSC), Bhubaneswar, India, 2016, pp. 1-5. https://doi.org/10.1109/NPSC.2016.7858909

[37] Elmer, G. "Novel high frequency model of transformers of electronic devices", PhD Thesis, Budapest University of Technology and Economics, 2006.

[38] Bjerkan, E., Høidalen, H. K. "High frequency FEM-based power transformer modeling: Investigation of internal stresses due to network-initiated overvoltages", Electric Power Systems Research, 77(11), pp. 1483-1489, 2007. https://doi.org/10.1016/j.epsr.2006.08.031

[39] Bjerkan, E., Høidalen, H., Moreau, O. "Importance of a proper iron core representation in high frequency power transformer models", In: Proceedings of the XIVth International Symposium on High Voltage Engineering, Tsinghua University, Beijing, China, 2005, pp. 25-29.

[40] Bjerkan, E. "High Frequency Modelling of Power Transformers: Stresses and Diagnostics", PhD Thesis, Norwegian University of Science and Technology, 2005.
[41] Martinez-Velasco, J. A. "Power System Transients: Parameter Determination", 1st ed., CRC Press, Boca Raton, FL, USA, 2009.

[42] Ziomek, W., Vijayan, K., Boyd, D., Kuby, K., Franchek, M. "High voltage power transformer insulation design", In: 2011 Electrical Insulation Conference (EIC), Annapolis, MD, USA, 2011, pp. 211-215. https://doi.org/10.1109/EIC.2011.5996148

[43] Krause, C. "Suitable pressboard insulation relevant dielectric design principles and assembly procedures for building reliable $1100 \mathrm{kV}$ ac power transformers", In: IEC/CIGRE UHV Symposium, Beijing, China, 2007, pp.1-10.

[44] Kuffel, E., Zaengl, W. S., Kuffel, J. "High Voltage Engineering", 2nd ed., Butterworth-Heinemann, Oxford, Great Britain, 2000.

[45] Németh, E., Horváth, T. "Nagyfeszültségű szigeteléstechnika" (High Voltage Insulation Systems), 2nd ed., Tankönyvkiadó, Budapest, Hungary, 1990. (in Hungarian)

[46] Tóth, Z., Cselkó, R. "Complex dielectric constant of various insulating fluids", In: 2016 Conference on Diagnostics in Electrical Engineering (Diagnostika), Pilsen, Czech Republic, 2016, pp. 1-4. https://doi.org/10.1109/DIAGNOSTIKA.2016.7736479

[47] Krehel', R., Kočiško, M., Poór, P. "Technical Diagnostics in the Paper Industry", In: Proceedings of the 27th DAAAM International Symposium, Vienna, Austria, 2016, pp. 775-784.

[48] Mehta, D. M., Kundu, P., Chowdhury, A., Lakhiani, V. K., Jhala, A. S. "A review on critical evaluation of natural ester visa-vis mineral oil insulating liquid for use in transformers: Part 1", IEEE Transactions on Dielectrics and Electrical Insulation, 23(2), pp.873-880, 2016. https://doi.org/10.1109/TDEI.2015.005370

[49] Fofana, I. "50 years in the development of insulating liquids", IEEE Electrical Insulation Magazine, 29(5), pp. 13-25, 2013. https://doi.org/10.1109/MEI.2013.6585853

[50] Vishal, S., Saurabh, Vikas, Prashant "Transformer's History and its Insulating Oil", In: Proceedings of the $5^{\text {th }}$ National Conference, INDIACom-2011, Computing For Nation Development, New Delhi, India, 2011, pp. 10-11.

[51] Gouda, O. E., Dessoky, M., Hassan, A. "Comparison between Oil Immersed and $\mathrm{SF}_{6}$ Gas Power Transformers Ratings", TELKOMNIKA (Telecommunication Computing Electronics and Control), 10(1), pp. 43-54, 2012.

[52] Mehta, D. M., Kundu, P., Chowdhury, A., Lakhiani, V. K., Jhala, A. S. "A review of critical evaluation of natural ester vis-avis mineral oil insulating liquid for use in transformers: Part II", IEEE Transactions on Dielectrics and Electrical Insulation, 23(3), pp. 1705-1712, 2016. https://doi.org/10.1109/TDEI.2016.005371

[53] Zhang, X., Wang, Z., Liu, Q., Jarman, P., Gyore, A., Dyer, P. "Numerical investigation of influences of coolant types on flow distribution and pressure drop in disc type transformer windings", In: 2016 International Conference on Condition Monitoring and Diagnosis (CMD), Xi'an, China, 2016, pp. 52-55. https://doi.org/10.1109/CMD.2016.7757761 
[54] Wang, Z., Liu, Q., Tee, S., Matharage, S., Jarman, P., Wilson, G., Hooton, R., Dyer, P., Walker, D., Krause, C., Smith, P. W. R., Mavrommatis, P., Gyore, A. "Ageing Assessment of Transformers through Oil Test Database Analyses and Alternative Diagnostic Techniques", In: CIGRE SC A2 Colloquium, Shanghai, China, 2015, article number: 0663.

[55] Liu, Z., Liu, Q., Wang, Z. D., Jarman, P., Krause, C., Smith, P. W. R., Gyore, A. "Partial discharge behaviour of transformer liquids and the influence of moisture content", In: 2014 IEEE $18^{\text {th }}$ International Conference on Dielectric Liquids (ICDL), Bled, Slovenia, 2014, pp. $1-4$.

https://doi.org/10.1109/ICDL.2014.6893155

[56] Schaible, M. "Electrical Insulating Papers - an Overview", IEEE Electrical Insulation Magazine, 3(1), pp. 8-12, 1987. https://doi.org/10.1109/MEI.1987.290616

[57] Sheppard, H. R. "A Century of Progress in Electrical Insulation 1886-1986", IEEE Electrical Insulation Magazine, 2(5), pp.20-30, 1986.

https://doi.org/10.1109/MEI.1986.290490

[58] Hettwer, P. F., Vu, V. H., "Improved Cellulosic Insulation for Distribution and Power Transformers", (No. EPRI-EL-4935). Cooper Industries, Inc., Franksville, WI (USA). McGraw-Edison Power Systems Div., Eletric Power Research Institute, Palo Alto, CA, USA, 1987.

[59] Coombs, A., Lindenmo, M., Snell, D., Power, D. "Review of the types, properties, advantages, and latest developments in insulating coatings on nonoriented electrical steels", IEEE Transactions on Magnetics, 37(1), pp. 544-557, 2001.

https://doi.org/10.1109/20.914376

[60] Tamus, Z. Á. "Complex diagnostics of insulating materials in industrial electrostatics", Journal of Electrostatics, 67(2-3), pp. $154-157,2009$.

https://doi.org/10.1016/j.elstat.2009.01.054

[61] Schwenterly, B., Pleva, E. "HTS Transformer Technology", presented at High Temperature Superconductivity for Electric Systems Peer Review, Arlington, Virginia, USA, Jul. 30, 2008.

[62] Vajda, I., Hyde, A., Gyore, A., Nador, G., Trollier, T., Sailer, B., Bohm, R. "Slimformer - Self-Limiting Transformer Pre-Prototype and Pilot Plant Design, Construction, and Tests", IEEE Transactions on Applied Superconductivity, 21(3), pp. 1298-1302, 2011. https://doi.org/10.1109/TASC.2011.2108251

[63] Vajda, I., Semperger, S., Porjesz, T., Szalay, A., Meerovich, V., Sokolovsky, V., Gawalek, W. "Three Phase Inductive HTS Fault Current Limiter for the Protection of a 12 kVA Synchronous Generator", IEEE Transactions on Applied Superconductivity, 11(1), pp. 2515-2518, 2001. https://doi.org/10.1109/77.920377

[64] Vajda, I., Gyore, A., Semperger, S., Baker, A., Chong, E. F. H., Mumford, F. J., Meerovich, V., Sokolovsky, V. "Investigation of High Ttemperature Superconducting Self-Limiting Transformer With YBCO Cylinder", IEEE Transactions on Applied Superconductivity, 17(2), pp. 1887-1890, 2007. https://doi.org/10.1109/TASC.2007.898144
[65] Sokolovsky, V., Meerovich, V., Vajda, I. "Comparison of a SelfLimiting Transformer and a Transformer Type FCL With HTS Elements", IEEE Transactions on Applied Superconductivity, 17(2), pp. 1911-1914, 2007. https://doi.org/10.1109/TASC.2007.899201

[66] Baldwin, T. L., Ykema, J. I., Allen, C. L., Langston, J. L. "Design Optimization of High-Temperature Superconducting Power Transformers", IEEE Transactions on Applied Superconductivity, 13(2), pp. 2344-2347, 2003. https://doi.org/10.1109/TASC.2003.813123

[67] Murta-Pina, J., Pereira, P., Ceballos, J. M., Álvarez, A., Amaro, N., Pronto, A., Silva, J., Arsénio, P. "Validation and Application of Sand Pile Modeling of Multiseeded HTS Bulk Superconductors", IEEE Transactions on Applied Superconductivity, 25(3), article number: 6801605, 2015. https://doi.org/10.1109/TASC.2014.2366073

[68] Arsénio, P., Silva, T., Vilhena, N., Pina, J. M., Pronto, A. "Analysis of Characteristic Hysteresis Loops of Magnetic Shielding Inductive Fault Current Limiters", IEEE Transactions on Applied Superconductivity, 23(3), article number: 5601004, 2013. https://doi.org/10.1109/TASC.2012.2235896

[69] Tihanyi, V., Gyore, A., Vajda, I. "Multiphysical Finite Element Modeling of Inductive Type Fault Current Limiters and Self Limiting Transformers", IEEE Transactions on Applied Superconductivity, 19(3), pp. 1922-1925, 2009. https://doi.org/10.1109/TASC.2009.2018101

[70] Újházy, G. "Eröátviteli transzformátorok tekercsrendszerének a méretezése" (Design of the power transformers winding system), Elektrotechnika, 62(10-11), pp. 450-459, 1969. (in Hungarian)

[71] Charley, R. M. "Recent progress in large transformers", Journal of the Institution of Electrical Engineers, 69(418), pp. 1189-1207, 1931. https://doi.org/10.1049/jiee-1.1931.0131

[72] Bohle, H. "Cape Town Local Section: Modern transformer design", Journal of the Institution of Electrical Engineers, 38(183), pp. 590-598, 1907. https://doi.org/10.1049/jiee-1.1907.0032

[73] Waldo, E. H. "Some Notes on Transformer Design", Transactions of the American Institute of Electrical Engineers, 48(3), pp. 821- 835, 1929.

https://doi.org/10.1109/T-AIEE.1929.5055298

[74] Vidmar, M. "Der kupferarme Transformator" (Transformers with Reduced Copper Loss), 1st ed., Springer, Berlin, Germany, 1935. (in German)

[75] Faye-Hansen, K. "Bemessung von Transformatoren" (Design of Transformers), Archiv für Elektrotechnik, 34(3), pp. 121-142, 1940. (in German) https://doi.org/10.1007/BF01657495

[76] Küchler, R. "Die Transformatoren: Grunlagen für ihre Berechnung und Konstrukion" (Transformers: Basics for their Calculation and Construction), 2nd ed., Springer-Verlag, Heidelberg, WestGermany 1966. (in German)

[77] Putman, T. H. "Economics and Power Transformer Design", IEEE Transactions on Power Apparatus and Systems, 82(69), pp. 1018$1023,1963$.

https://doi.org/10.1109/TPAS.1963.291486 
[78] Orosz, T., Tamus, Z. Á. "Impact of the Cooling Equipment on the Key Design Parameters of a Core-Form Power Transformer", Journal of Electrical Engineering, 67(6), pp. 399-406, 2016. https://doi.org/10.1515/jee-2016-0058

[79] Adly, A. A., Abd-El-Hafiz, S. K. "A performance-oriented power transformer design methodology using multi-objective evolutionary optimization", Journal of Advanced Research, 6(3), pp. 417-423, 2015 https://doi.org/10.1016/j.jare.2014.08.003

[80] Sharpley, W. A., Oldfield, J. V. "The digital computer applied to the design of large power transformers", Proceedings of the IEE Part A: Power Engineering, 105(20), pp. 112-121, 1958. https://doi.org/10.1049/pi-a.1958.0029

[81] Williams, S. B., Abetti, P. A., Mason, H. J. "Complete Design of Power Transformers with a Large-Size Digital Computer", Transactions of the American Institute of Electrical Engineers, Part III: Power Apparatus and Systems, 77(3), pp. 1282-1291, 1958. https://doi.org/10.1109/AIEEPAS.1958.4500143

[82] Dicső, L., Petrás, I. "Transzformátorok számítása elektronikus számítogéppel" (Calculation of Transformers with Computer), Ganz Villamossági Közlemények, 3, pp. 19-24, 1966.

[83] Kiss, L. "Transzformátor sorozatok kialakítasának egyes kérdései" (Questions for the Construction of the Transformers Series), Ganz Villamossági Közlemények, 3, pp. 3-18, 1966.

[84] Abetti, P. A., Maginniss, F. J. "Natural Frequencies of Coils and Windings Determined by Equivalent Circuit", Transactions of the American Institute of Electrical Engineers, Part III: Power Apparatus and Systems, 72(3), pp. 495-504, 1953. https://doi.org/10.1109/AIEEPAS.1953.4498660

[85] Abetti, P. A. "Transformer Models for the Determination of Transient Voltages", Transactions of the American Institute of Electrical Engineers, Part III: Power Apparatus and Systems, 72(3), pp. 468-480, 1953. https://doi.org/10.1109/AIEEPAS.1953.4498656

[86] Rabins, L. "Transformer reactance calculations with digital computers", Transactions of the American Institute of Electrical Engineers, Part I: Communication and Electronics, 75(3), pp. 261267, 1956. https://doi.org/10.1109/TCE.1956.6372526

[87] Andersen, O. W. "Transformer Leakage Flux Program Based on the Finite Element Method", IEEE Transactions on Power Apparatus and Systems, PAS-92(2), pp. 682-689, 1973. https://doi.org/10.1109/TPAS.1973.293773

[88] Rabins, L. "A New Approach to the Analysis of Impulse Voltages and Gradients in Transformer Windings", Transactions of the American Institute of Electrical Engineers, Part III: Power Apparatus and Systems, 78(4), pp. 1784-1791, 1959. https://doi.org/10.1109/AIEEPAS.1959.4500660

[89] Andersen, O. W. "Large transformers for power electronic loads", IEEE Transactions on Power Delivery, 12(4), pp. 1532-1537, 1997. https://doi.org/10.1109/61.634172

[90] Andersen, O. W. "Finite element solution of skin effect and eddy current problems", In: IEEE PES Summer Power Meeting, Mexico City, Mexico, July 1977, Paper A-77-616-6.

[91] Khatri, A., Rahi, O. P. "Optimal Design of Transformer: A Compressive Bibliographical Survey", International Journal of Scientific Engineering and Technology, 1(2), pp. 159-167, 2012.
[92] Kuczmann, M., Iványi, A. "The Finite Element Method in Magnetics", 1st ed., Akadémiai Kiadó, Budapest, Hungary, 2008.

[93] Tóth, B. "Multi-field Dual-Mixed Variational Principles Using Non-symmetric Stress Field in Linear Elastodynamics", Journal of Elasticity, 122(1), pp. 113-130, 2016. https://doi.org/10.1007/s10659-015-9535-4

[94] Tóth, B. "Dual and mixed nonsymmetric stress-based variational formulations for coupled thermoelastodynamics with second sound effect", Continuum Mechanics and Thermodynamics, 30(2), pp. 319-345, 2018 https://doi.org/10.1007/s00161-017-0605-7

[95] Tóth B., Kocsán, L. G. "Comparison of dual-mixed h- and p-version finite element models for axisymmetric problems of cylindrical shells", Finite Elements in Analysis and Design, 65, pp. 50-62, 2013.

https://doi.org/10.1016/j.finel.2012.11.002

[96] Solin, P., Dolezel, I., Karban, P., Ulrych, B. "Integral Methods in Low-Frequency Electromagnetics", John Wiley \& Sons, Hoboken, NJ, USA, 2009.

[97] Amoiralis, E. I., Tsili, M. A., Georgilakis, P. S., Kladas, A. G. "Energy Efficient Transformer Selection Implementing Life Cycle Costs and Environmental Externalities", In: 9th International Conference. Electrical Power Quality and Utilisation, Barcelona, Spain, 2007, pp. 1-6.

[98] Karban, P., Mach, F., Kůs, P., Pánek, D., Doležel, I. "Numerical solution of coupled problems using code Agros2D", Computing, 95(Supplement 1), pp. 381-408. https://doi.org/10.1007/s00607-013-0294-4

[99] Šolín, P., Červený, J., Doležel, I. "Arbitrary-level hanging nodes and automatic adaptivity in the hp-FEM", Mathematics and Computers in Simulation, 77(1), pp. 117-132, 2008. https://doi.org/10.1016/j.matcom.2007.02.011

[100] Karban, P., Pánek, D., Kropik, P. "Utilization of Algebraic Multigrid for Solving Electromagnetic Field by HP-FEM", In: 2016 ELEKTRO, Strbske Pleso, Slovakia, 2016, pp. 527-532, 2016. https://doi.org/10.1109/ELEKTRO.2016.7512132

[101] Doležel, I., Karban, P., Kropík, P., Kotlan, V., Pánek, D. "Optimized control of field current in thermoelastic actuator for accurate setting of position", Applied Mathematics and Computation, 219(13), pp. 7187-7193, 2013 https://doi.org/10.1016/j.amc.2011.06.008

[102] Булгаков, Н. И. "Расчет трансформаторов" (Transformer calculations), Государственное энергетическое издательство, Москва, 1950. (in Russian)

[103] Csikós, B. "A legkisebb üzemi költségü transzformátor" (Transformer with minimal load loss), Elektrotechnika, 55(6), pp. 259-267, 1962. (in Hungarian)

[104] Orosz, T., Sleisz, Á., Vajda, I. "Core-form transformer design optimization with branch and bound search and geometric programming", In: 2014 55th International Scientific Conference on Power and Electrical Engineering of Riga Technical University (RTUCON), Riga, Latvia, 2014, pp. 17-21. https://doi.org/10.1109/RTUCON.2014.6998194

[105] Csikos, B. "A gazdaságos transzformátorüzem" (Cost effective operation of transformers), Elektrotechnika, 543), pp. 103-119, 1961. (in Hungarian) 
[106] Luspay, Z. "Gazdaságos transzformátorok tervezésének új szempontjai" (Aspects of the design of cost optimal transformers), Ganz Villamossági Közlemények, 22, pp. 63-68, 1984. (in Hungarian)

[107] Kennedy, B.W. "Energy efficient transformers", McGraw-Hill Professional Publishing, Blacklick, USA, 1998.

[108] Jakielski, T. "Computer design of small power transformers and inductors", presented at IEEE Winter General Conference, New York, NY, January 27-February 1, 1963.

[109] Shull, D. "Rapid design of electronic power transformers using a computer time-sharing system", IEEE Transactions on Magnetics, 5(3), pp. 534-535, 1969. https://doi.org/10.1109/TMAG.1969.1066477

[110] Odessey, P. "Transformer Design by Computer", IEEE Transactions on Manufacturing Technology, 3(1), pp. 1-17, 1974. https://doi.org/10.1109/TMFT.1974.1135672

[111] Reeves, P. E. "Computer aided design of power converter transformers", In: Proceedings of Workshop on Applied Magnetics, Washington DC., USA, 1972, pp. 1-10.

[112] Palmer, M. "Small transformer design by computer", DTIC Document, 1974.

[113] Davis, J. "Fast optimization of transformer design", Electrical Design News, 7(12), pp. 86-101, 1962.

[114] Turkington, R. E. "Effect of operating frequency on the weight and other characteristics of missile alternators and transformers", Transactions of the American Institute of Electrical Engineers, Part II: Applications and Industry, 77(5), pp. 289-300, 1958. https://doi.org/10.1109/TAI.1958.6367336

[115] Garbarino, H. L. "Some Properties of the Optimum Power Transformer Design", Transactions of the American Institute of Electrical Engineers. Part III: Power Apparatus and Systems, 73(1), pp. 675-683, 1954. https://doi.org/10.1109/AIEEPAS.1954.4498874

[116] Grossner, N. R. "Transformers for electronic circuits", McGrawHill, New York, USA, 1967.

[117] Lee, R., Wilson, L., Carter, C. E. "Electronic transformers and circuits", Wiley-Interscience, New York, USA, 1988.

[118] Andersen, O. W. "Optimized design of electric power equipment", IEEE Computer Applications in Power, 4(1), pp. 11-15, 1991. https://doi.org/10.1109/67.65030

[119] Vodovozov, V., Raud, Z., Bakman, I., Lehtla, T., Gevorkov, L. "Hardware-in-the-loop simulator of vessel electric propulsion drive", In: 2015 9th International Conference on Compatibility and Power Electronics (CPE), Costa da Caparica, Portugal, 2015, pp. $425-430$.

https://doi.org/10.1109/CPE.2015.7231113

[120] Saravolac, M. P. "Use of advanced software techniques in transformer design," In: IEE Colloquium on Design Technology of T\&D Plant, Durham, UK, 1998, pp. 1-11. https://doi.org/10.1049/ic:19980458

[121] Judd, F., Kressler, D. "Design Optimization of Small LowFrequency Power Transformers", IEEE Transactions on Magnetics, 13(4), pp. 1058-1069, 1977. https://doi.org/10.1109/TMAG.1977.1059509

[122] Poloujadoff, M., Findlay, R. D. "A Procedure for Illustrating the Effect of Variation of Parameters on Optimal Transformer design", IEEE Transactions on Power Systems, 1(4), pp. 202-205, 1986. https://doi.org/10.1109/TPWRS.1986.4335043
[123] IEEE "C57.120-1991, IEEE Loss Evaluation Guide for Power Transformers and Reactors", IEEE, USA, 1992. https://doi.org/10.1109/IEEESTD.1992.114388

[124] Tačković, K., Petrović, I., Glavaš, H. "Energy efficient transformers", In: HRVATSKI OGRANAK MEĐUNARODNE ELEKTRODISTRIBUCIJSKE KONFERENCIJE-HO CIRED, Trogir, Croatia, 2014, pp. 1-11.

[125] Hammons, T. J., Kennedy, B., Lorand, R., Thigpen, S., McConnell, B. W., Rouse, S., Prevost, T. A., Pruess, C., Dade, S. J., Ramanan, V. R., Baldwin, T. L. "Future Trends in Energy-efficient Transformers", IEEE Power Engineering Review, 18(7), pp. 5-16, 1998. https://doi.org/10.1109/MPER.1998.686948

[126] Charalambous, C. A., Milidonis, A., Lazari, A., Nikolaidis, A. I. "Loss Evaluation and Total Ownership Cost of Power Transformers-Part I: A Comprehensive Method", IEEE Transactions on Power Delivery, 28(3), pp. 1872-1880, 2013. https://doi.org/10.1109/TPWRD.2013.2262506

[127] Charalambous, C. A., Milidonis, A., Hirodontis, S., Lazari, A. "Loss Evaluation and Total Ownership Cost of Power TransformersPart II: Application of Method and Numerical Results", IEEE Transactions on Power Delivery, 28(3), pp. 1881-1889, 2013. https://doi.org/10.1109/TPWRD.2013.2262507

[128] Georgilakis, P., Fofana, I., Olivares-Galvan, J. C., EscarelaPerez, R., Fofana, I., Stefopoulos, G. K. "Environmental Cost of Transformer Losses for Industrial and Commercial Users of Transformers", In: 2011 North American Power Symposium (NAPS), Boston, MA, USA, 2011, pp. 1-4. https://doi.lorg/10.1109/NAPS.2011.6024860

[129] Holland, S., O’Connell, G. P., Haydock, L. "Calculating stray losses in power transformers using surface impedance with finite elements", IEEE Transactions on Magnetics, 28(2), pp. 1355-1358, 1992. https://doi.org/10.1109/20.123943

[130] Leite, J. V., Benabou, A., Sadowski, N., da Luz, M. V. F. "Finite Element Three-Phase Transformer Modeling Taking Into Account a Vector Hysteresis Model", IEEE Transactions on Magnetics, 45(3), pp. 1716-1719, 2009. https://doi.org/10.1109/TMAG.2009.2012794

[131] McLyman, C. W. T. "Transformer and inductor design handbook", 3rd ed., Boca Raton, USA, 2004.

[132] Kulkarni, S. V., Khaparde, S. A. "Stray Loss Evaluation in Power Transformers - A Review", In: 2000 IEEE Power Engineering Society Winter Meeting. Conference Proceedings (Cat. No.00CH37077), Singapore, Singapore, 2000, pp. 2269-2274. https://doi.org/10.1109/PESW.2000.847708

[133] Wang, Q., Janghorban, S., Yu, X., Holmes, G. "Computer-aided power transformer design: A short review", In: 2013 Australasian Universities Power Engineering Conference (AUPEC), 2013, pp. 1-6.

[134] Hernandez, C., Arjona, M. A., Dong, S.-H. "Object-Oriented Knowledge-Based System for Distribution Transformer Design", IEEE Transactions on Magnetics, 44(10), pp. 2332-2337, 2008. https://doi.org/10.1109/TMAG.2008.2001483

[135] Georgilakis, P. S. "Recursive genetic algorithm-finite element method technique for the solution of transformer manufacturing cost minimisation problem", IET Electric Power Applications, 3(6), pp. 514-519, 2009.

https://doi.org/10.1049/iet-epa.2008.0238 
[136] Zhang, Z., Pan, Z., Pan, X. "A regression analysis based heuristic method to the power transformer design optimization problem", In: 2011 International Conference on Electrical Machines and Systems, Beijing, China, 2011, pp. 1-4. https://doi.org/10.1109/ICEMS.2011.6073345

[137] Mohan, N., Robbins, W. P., Undeland, T. M. "Power electronics: converters, applications, and design", 3rd ed., John Wiley \& Sons, Hoboken, NJ, USA, 2007.

[138] Georgilakis, P. S., Tsili, M. A., Souflaris, A. T. "A heuristic solu tion to the transformer manufacturing cost optimization problem", Journal of Materials Processing Technology, 181(1-3), pp. 260-266, 2007. https://doi.org/10.1016/j.jmatprotec.2006.03.034

[139] Amoiralis, E. I., Tsili, M. A., Kladas, A. G. "Global transformer design optimization using deterministic and non-deterministic algorithms", In: 2012 XXth International Conference on Electrical Machines, Marseille, France, 2012, pp. 2323-2331. https://doi.org/10.1109/ICElMach.2012.6350207

[140] Yadollahi M., Lesani, H. "Power transformer optimal design using an innovative heuristic algorithm combined with mix integer non-linear programming and FEM technique", IET Generation, Transmission \& Distribution, 11(13), pp. 3359-3370, 2017. https://doi.org/10.1049/iet-gtd.2017.0151

[141] Yadollahi, M., Lesani, H. "Power transformer optimal design (PTOD) using an innovative heuristic method combined with FEM technique", Electrical Engineering, 100(2), pp. 823-838, 2018. https://doi.org/10.1007/s00202-017-0537-z

[142] Pham, T. H., Salon, S. J., Hoole, S. R. H. "Shape optimization of windings for minimum losses", IEEE Transactions on Magnetics, 32(5), pp. 4287-4289, 1996. https://doi.org/10.1109/20.538845

[143] Geromel, L. H., Souza, C. R. "The application of intelligent systems in power transformer design", In: Proceedings of the 2002 International Joint Conference on Neural Networks. IJCNN'02 (Cat. No.02CH37290), Honolulu, HI, USA, 2002, pp. 1504-1509. https://doi.org/10.1109/IJCNN.2002.1007740

[144] Doulamis, N. D., Doulamis, A. D., Georgilakis, P. S., Kollias, S. D., Hatziargyriou, N. D. "A synergetic neural network-genetic scheme for optimal transformer construction", Integrated Computer-Aided Engineering, 9(1), pp. 37-56, 2002. https://doi.org/10.3233/ICA-2002-9103

[145] Yang, X.-S. "Nature-inspired metaheuristic algorithms", 2nd ed., Luniver Press, Frome, UK, 2010.

[146] Selvi, S. T., Baskar, S., Rajasekar, S. "Chapter 17 - Application of Evolutionary Algorithm for Multiobjective Transformer Design Optimization", In: Zobaa, A. F., Abdel Aleem, S. H. E., Abdelaziz, A. Y. (eds.) Classical and Recent Aspects of Power System Optimization, 1st ed., Elsevier Ltd.: Academic Press, 2018, pp. 463-504.

https://doi.org/10.1016/B978-0-12-812441-3.00017-3

[147] Soldoozy, A., Esmaeli, A., Akbari, H., Mazloom, S. Z. "Implementation of tree pruning method for power transformer design optimization", International Transactions on Electrical Energy Systems, p. e2659, 2018. https://doi.org/10.1002/etep.2659
[148] Amoiralis, E. I., Georgilakis, P. S., Tsili, M. A. , Kladas, A. G. "Global Transformer Optimization Method Using Evolutionary Design and Numerical Field Computation", IEEE Transactions on Magnetics, 45(3), pp. 1720-1723, 2009. https://doi.org/10.1109/TMAG.2009.2012795

[149] Hui, L., Li, H., Bei, H., Shunchang, Y. "Application research based on improved genetic algorithm for optimum design of power transformers", In: ICEMS'2001. Proceedings of the Fifth International Conference on Electrical Machines and Systems (IEEE Cat. No.01EX501), Shenyang, China, 2001, pp. 242-245. https://doi.org/10.1109/ICEMS.2001.970657

[150] Khatri, A., Malik, H., Rahi, O. P. "Optimal Design of Power Transformer Using Genetic Algorithm", In: 2012 International Conference on Communication Systems and Network Technologies, Rajkot, India, 2012, pp. 830-833. https://doi.org/10.1109/CSNT.2012.180

[151] Mehta, H. D., Patel, R. M., Trivedi, P. H. "Cost estimation of transformer main materials using Artificial Neural Networks", In: 2012 Nirma University International Conference on Engineering (NUiCONE), Ahmedabad, India, 2012, pp. 1-6. https://doi.org/10.1109/NUICONE.2012.6493275

[152] Baodong, B., Dexin, X., Jiefan, C., Mohammed, O. A. "Optimal transposition design of transformer windings by Genetic Algorithms", IEEE Transactions on Magnetics, 31(6), pp. 3572-3574, 1995. https://doi.org/10.1109/20.489573

[153] Tsili, M. A., Kladas, A. G., Georgilakis, P. S., Souflaris, A. T., Paparigas, D. G. "Geometry optimization of magnetic shunts in power transformers based on a particular hybrid finite-element boundary-element model and sensitivity analysis", IEEE Transactions on Magnetics, 41(5), pp. 1776-1779, 2005. https://doi.org/10.1109/TMAG.2005.846075

[154] Wu, W. "CFD calibrated thermal network modelling for oilcooled power transformers" PhD Dissertation, The University of Manchester, UK, 2011

[155] Boyd, S., Mattingley, J. "Branch and bound methods", Notes for EE364b, Stanford University, pp. 2006-07, 2007.

[156] Burer, S., Letchford, A. N. "Non-convex mixed-integer nonlinear programming: A survey", Surveys in Operations Research and Management Science, 17(2), pp. 97-106, 2012 https://doi.org/10.1016/j.sorms.2012.08.001

[157] Amoiralis, E. I., Tsili, M. A., Georgilakis, P. S., Kladas, A. G., Souflaris, A T. "A Parallel Mixed Integer Programming-Finite Element Method Technique for Global Design Optimization of Power Transformers", IEEE Transactions on Magnetics, 44(6), pp. 1022-1025, 2008. https://doi.org/10.1109/TMAG.2007.915119

[158] Duffin, R. J., Peterson, E. L., Zener, C. "Geometric programming: theory and application", Wiley, New York, USA, 1967.

[159] Jabr, R. A. "Application of Geometric Programming to Transformer Design", IEEE Transactions on Magnetics, 41(11), pp. 4261-4269, 2005. https://doi.org/10.1109/TMAG.2005.856921

[160] Boyd, S. P., Vandenberghe, L. "Convex optimization", Cambridge University Press, Cambridge, UK, 2004.

[161] Boyd, S., Kim, S.-J., Vandenberghe, L., Hassibi, A. "A tutorial on geometric programming", Optimization and Engineering, 8(1), pp. $67-127,2007$.

https://doi.org/10.1007/s11081-007-9001-7 